ANNA BOMANOWSKA ${ }^{1} \&$ MARCIN KIEDRZYŃSKI ${ }^{2}$

Department of Geobotany and Plant Ecology, University of Łódź, Banacha 12/16, 90-237 Łódź, Poland, ${ }^{1}$ knopikaa@ biol.uni.lodz.pl, ${ }^{2}$ kiedmar@ biol.uni.lodz.pl

\title{
CHANGING LAND USE IN RECENT DECADES AND ITS IMPACT ON PLANT COVER IN AGRICULTURAL AND FOREST LANDSCAPES IN POLAND
}

\begin{abstract}
The objective of this paper is to present the effects of general changes in land use in recent decades on plant cover structure in Poland. The paper is focused on spontaneous processes that occur in agricultural and forest areas being no longer under human pressure. Studies carried out in different geobotanical regions of Poland demonstrated that the directions and range of dynamic changes in plant cover are similar across the country. The formation of secondary forest phytocenoses, on the lands delivered from human activity is a common ecological process observed today in the agricultural landscape. In the dynamics of forest vegetation the basic process is regeneration after ceased use, and the introduction of legal protection.
\end{abstract}

Key words: cultural landscape, human disturbance, land use changes, regeneration, secondary succession, vegetation dynamics processes

\section{INTRODUCTION}

Over the last several thousand years the natural environment on the Earth has been transforming particularly rapidly due to the growing needs of a single species Homo sapiens. Currently, the human pressure on our planet is so strong that the name of a new epoch - the anthropocene - is being used more and more frequently (CRUTZEN 2002; CrutZen, STEFFEN 2003; ZALASIEWICZ et al. 2008). The beginning of the $20^{\text {th }}$ century can be assumed as the starting point of this period, when 
population size and consumption rate rapidly increased, and humans dominated nature and became the major factor shaping ecological systems.

The intensity of human activity fluctuates depending on historical period and geographical region (SUKOPP 1972; FOLEY et al. 2005). Because of surges of civilization changes, natural areas previously seized by humans recover their former status during periods of economic slowdown or because of advances in technology. Therefore, the present vegetation cover is a mosaic comprising patches which undergo dramatic changes, and those where succession and regeneration lead to the naturalization of ecological systems (FALIŃSKI 1986a; ELLENBERG 1988; VAN DER MAAREL 1988).

The objective of this paper is to present the effects of general changes in land use in recent decades on plant cover structure in Poland. Due to the extensive range and complexity of the discussed problem this paper is focused solely on general transformations in agricultural and forest areas, without reference to urban and industrial areas. Major interest is focused on spontaneous processes that occur in land being no longer under human pressure. Our article was inspired by papers on various aspects of dynamic transformation in plant cover in Poland, published in the current volume of Folia Biologica et Oecologica no. 7/2011.

\section{GENERAL DIRECTIONS OF LAND USE CHANGES IN EUROPE OVER THE LAST TWO CENTURIES}

Over about 5,000 years of agricultural history in Europe, the anthropogenic transformation of natural woodlands into mosaic landscapes with agricultural and semi-natural habitats has had the considerable side-effect of enhancing the diversity of vascular plants, biocoenoses and ecosystems (SUKOPP 1972; WALDHARDT et al. 2003). The highest diversity of plant cover in Europe was recorded in the $18^{\text {th }}$ and early $19^{\text {th }}$ centuries (SUKOPP 1972; ELLENBERG 1988; BAKKER 2005). Various extensive forms of use resulted in the permanent preservation of meadows, grasslands, pastures, forest edge communities and thermophilous forests (BAKKER 2005). In farming and forest areas unaffected by urbanization and industry, plant cover adapted to the specific way of use, which involved periodically repeated forms 
of human pressure (OLACZEK 1972). However, in those times human pressure did not yet result in significant changes in general environmental conditions, water and soil regime, or climate (SUKOPP 1972; KORNAŚ 1977).

In the middle of the twentieth century, the situation changed dramatically. Traditional and diverse management practices, which had been the main driving forces for the increase and preservation of biodiversity, were given up and were replaced by modern agriculture. Intensification of agriculture through the use of high-yielding crop varieties, fertilization, irrigation, and pesticides has contributed substantially to tremendous increases in food production over the past 50 years (MATSON et al. 1997). At the same time, many marginal areas with an unfavourable climate, topography and poor soils are threatened by abandonment. Such rural landscapes, with a traditional small-scale mosaic of grassland and arable fields, and thus a high diversity of habitats, have undergone radical change since crop production has been widely replaced by extensively managed grasslands or even forests in the past few decades (WALDHARDT et al. 2003).

These opposing processes have led to a decrease in biodiversity, which continues to be observed today, particularly in Western Europe (ELLENBERG 1988; BAKKer 2005; Hodgson et al. 2005; Poschlod et al. 2005; Petit, Firbank 2006; REIDSMA et al. 2006; NIEDRIST et al. 2009).

In Europe the end of the $20^{\text {th }}$ century brought further human-induced changes which had a significant effect on land use (POSCHLOD et al. 2005). The availability of inexpensive food imported from distant countries, changes in life style, and migration of people from rural to urban areas in search of jobs, have been causing the abandonment of areas formerly under human use (ELLENBERG 1988). These areas have became forested, or used for the construction of new residential estates, holiday resorts, or for public, transport and industrial infrastructure. Such a process has certain effects on the structure and dynamics of plant cover. Grasslands, arable fields and meadows become covered with trees, and young and secondary forests are formed, which are difficult to classify to the existing phytosociological units. Species banks in the landscape change, and the surface of grassland and meadow communities - remnants of former use - are reduced, until total decline occurs. The 
isolation of semi-natural vegetation patches has become a considerable problem (PETIT, FIRBANK 2006). The restoration of floristically rich meadows and grasslands is today greatly inhibited due to the limited migration opportunities of plants which were formerly dispersed by, e.g. domestic animals (POSCHLOD et al. 1998; BĄBA 2003; DZWONKO, LOSTER 2007).

In the middle of the $20^{\text {th }}$ century some changes in European forest ecosystems have been caused by abandonment of use. Forests were no longer used for grazing, the collection of litter and faggots, or controlled burning (ELLENBERG 1988; FALIŃSKI 1986 a, 1988 a; BENGTSSON et al. 2000; ZERBE 2002).

At present after decades of executing technical and economic forest management, e.g. cultivation of coniferous monocultures, the so-called biological rationalisation methods are being introduced. Not only the answer for the question: "What to do to forge a sustained, stabile, biologically diverse and efficient forest?" is being sought but also "What not to do yet to achieve this target?" (PALUCH 2006).

Changes in silviculture theory and practice today result in the observed spontaneous regeneration of forest communities, reflected in such processes as increased share of deciduous trees and shrubs, and number of species characteristic for mesophilous and shady habitats. The encroachment of broad-leaved tree species and habitat fertilization often cause a decline in thermophilous and heliophilous species, whose occurrence may be connected with the management of forests in the past (e.g. TYBIRK, STRANDBERG 1999). Regeneration mainly occurs in protected forest areas where use is limited or has completely ceased (FALIŃSKI 1986 a).

When the above-described changes in agricultural and forest landscapes occur simultaneously over large areas they lead to a change in regional species polls, which may significantly influence the future formation of new species compositions (BENGTSSON et al. 2000; NAAF, WOLF 2011).

\section{NATURE OF CHANGES IN LANDSCAPE MANAGEMENT IN THE $20^{\text {TH }}$ CENTURY IN POLAND}

The formation of plant cover in Poland has been under the influence of various natural and cultural factors (SZAFER 1977). Plant cover is highly diversified 
and includes: almost primeval communities, semi-natural and markedly anthropogenic communities. In general, the natural environment in Poland is preserved in a better condition than in other parts of the Central European Plain, and biodiversity in Poland has one of the highest levels in Europe (ANDRZEJEWSKI, WeIGLE 2003). This is influenced both by natural conditions and, different from other European countries, the nature of human pressure, for example uneven distribution of industrial and urban areas in Poland, as well as extensive farming on a large scale. The cultural landscape of the Polish countryside is unique on European scale because historical circumstances prevented Polish agriculture from doctrinebased collectivisation or large-acreage farming driven by the free market.

Changes that occurred in the Polish natural environment in recent centuries have been unevenly distributed and determined by political and social factors. On the land annexed by Prussia changes in plant cover caused by the developing civilization were similar to those in Western Europe, while in other regions they occurred with delay. This particularly refers to eastern and south-eastern regions of Poland, where the structure of farming land is highly fragmented, and where traditional farming methods continue to be used.

The transformations that occurred in Poland after World War II had a significant effect on intensified changes in land use. In Poland, under a new system, the migration of people and changes in land use took forms unknown before (CioŁkosz, PoŁAWsKi 2006). Abandoned and fallow lands were not uncommon in Poland in the period between the wars, yet the acreage of arable fields, meadows and pastures has been rapidly decreasing since 1938 (Fig. 1). The dramatic decrease in acreage occurred during and after WWII. In the 1940s, because of war damage and migration of people, fallow lands covered a considerable part of Poland, particularly in Regained Territories. In the 1950s and 1960s, during post-war reconstruction and development, the reduction in agricultural acreage was inhibited (Fig.1). Further reduction in agricultural acreage, and the emergence of lands left fallow for social and economic reasons, was associated with social and economic transformations that had led to the migration of people from rural to urban areas, and which continued gradually until as late as the 1980s (BAŃSKI 1997). 
Another phase of growth in fallow land area followed the transformation of the political system between the end of the 1980s and the early 1990s (Fig. 1). This process was determined by various factors, e.g. economic, financial, poor soil quality and high fragmentation of farms (NOWICKI et al. 1998).

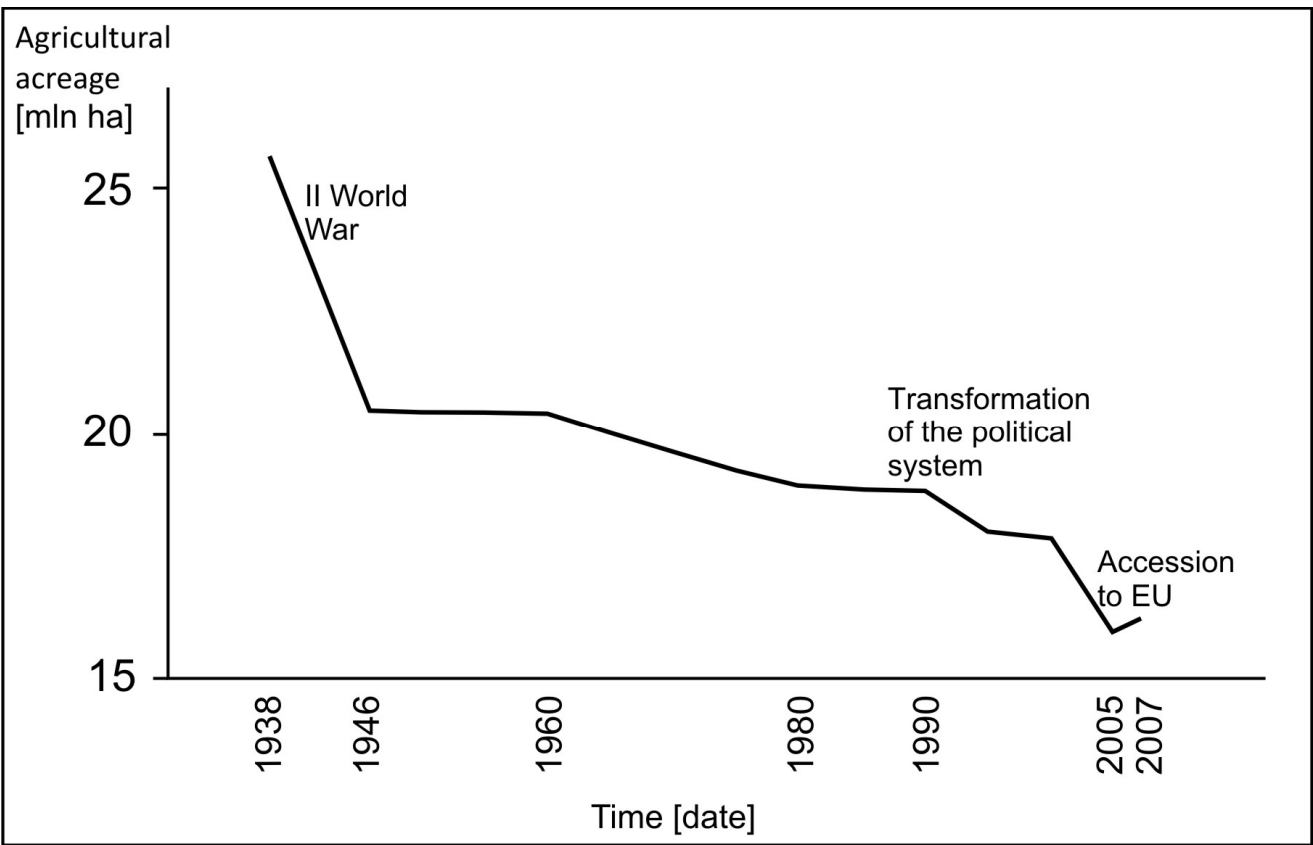

Fig. 1. Changes in agricultural area between 1938 and 2007 in Poland (based on data from URBAN 2009).

In the early $21^{\text {st }}$ century further significant changes in the structure of agricultural areas were observed in Poland (Fig. 1). The accession of Poland to the European Union, and previous economic problems in Polish agriculture (e.g. decline of state-owned farms), compelled fallowing on a considerable area of agricultural land (Plan RozWoJU 2004-2006; Program RozWOJU 2007-2013). After the accession of Poland to the EU the area of meadows and pastures increased slightly (Fig. 1), due to the introduction of EU direct subsidies and agri-environmental programmes, but, unfortunately, lands recovered to use are not in general as valuable in terms of natural features as those which have been lost within the past several decades. 
Elimination of land from agricultural use triggers secondary succession, which is one of the major threats to the existence of valuable semi-natural communities in the landscape. In certain regions previously dominated by meadows and pastures farming was completely eliminated, while in others agriculture moved to more fertile soils, e.g. those located in drained areas. This has led to the decline of many patches of semi-natural meadow, moor and marshy communities (see: JASNOWSKI et al. 1968; JASNOWSKI 1972; FALKOWSKI 1983; KORNAŚ, DUBIEL 1990; OlaCZEK et al. 1990; BARABASZ 1994; HerbichOWA 1998; KUCHARSKI 1999). For similar reasons grazing on thermophilous grasslands, whose existence is dependent on extensive use, was abandoned (see: MichALIK 1990 a; SENDEK, BABCZYŃSKASENDEK 1990; FIJAŁKOWSKI, ŚWIERCZYŃSKA 1991; DZWONKO, LOSTER 1998; WALDON 1999).

Another process parallel to fallowing is intensified agricultural practice (Program RozWOJU 2007-2013), which, combined with land integration, leads to a further decrease in mosaic habitats, a reduction in the area of semi-natural communities, and elimination of woodstands, ponds and boundary strips, as well as the isolation of populations of stenotopic species.

Reduction in the area of semi-natural meadows and grasslands in the $20^{\text {th }}$ century occurred with the simultaneous increase in forested areas and those intended for settlement and industrial use. After the period of 'hunger for wood and land' in the $19^{\text {th }}$ century, which led to considerable deforestation (OLACZEK 1972), the area of forests increased by over $15,000 \mathrm{~km}^{2}$ in 1930-2000, and the forestation rate in Poland increased from $20.8 \%$ in 1945 to $29.2 \%$ in 2010 (GUS 2010). These changes had a clearly regional nature and occurred mainly in north-western and south-eastern parts of Poland (Fig. 2). The forestation rate increased significantly in such regions as the Bieszczady Mountains and their vicinity (WOLSKI 2007), and in Regained Territories in western and northern Poland. This was associated with political transformations and the massive resettlement of people after Word War II (JuTRZENKA-TRZEBIATOWSKi 1999; CiOŁKOSZ, POŁAWSKi 2006; WOLSKi 2007). 


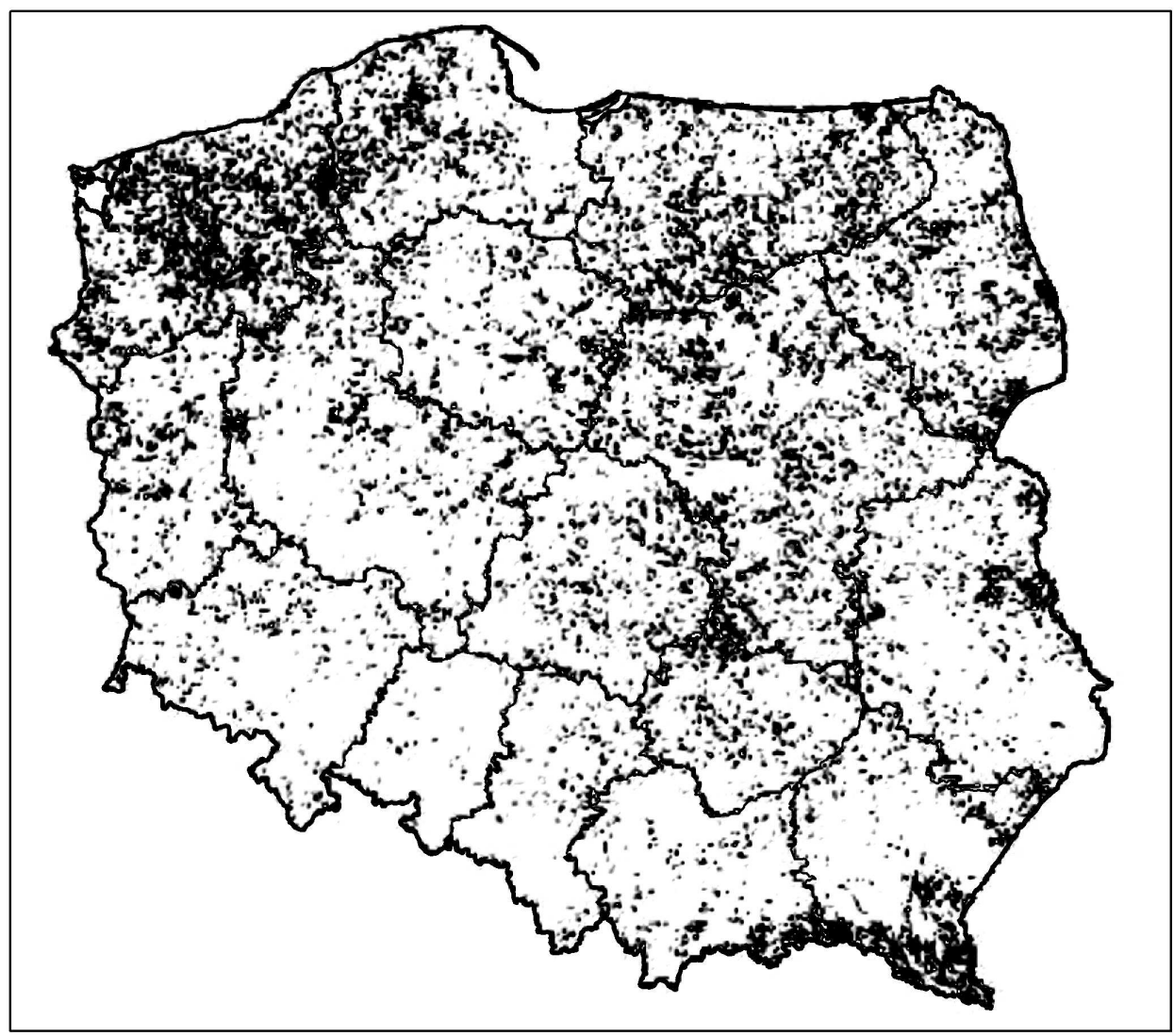

Fig. 2. Areas of recorded increase in forest cover in Poland 1930-2000 (after CiOŁKosz, PoŁAwsKi 2006, modified).

A question of whether areas eliminated from agricultural use should be aforested or instead left until the spontaneous forest return is more and more frequently raised (WóJCIK 1996; BALCERKIEWICZ 1997; KUJAWA-PAWLACZYK, PAWlaCZyK 1997; SzWAGRZYK 1997; JERMACZEK 2008; MATYSIAK, DEMBEK 2008). Forestation causes a permanent change in land use, requires considerable financial input, and is time-consuming and labour-intensive (REWUCKI 2008; SKOLUD 2008). On the other hand, several hundred years may be needed for spontaneous forest return (FALIŃSKI 1986a,b; BOMANOWSKA, ADAMOWSKI 2007, 2009), and this process does not always lead to the recovery of the former forest community (GRINN-GOFROŃ 2007; KUJAWA-PAWLACZYK, PAWLACZYK 1997; ŁASKA 1997). The species composition in secondary forests established during spontaneous or assisted succession depends, for example, on the availability of diaspores of ancient forest species. Therefore, the ability of plants to migrate within 
the landscape is the key factor determining the time needed for regeneration and naturalization of the discussed natural systems (DZWONKO, LOSTER 1992; ORCZEWSKA, FERNES 2011). Many authors (RICHARDSON et al. 1994; FALIŃSKI 1998b; REJMÁNeK 1999; BARABASZ-KRASNy 2002; MEINERS et al. 2002; ADAMOWSKI, BOMANOWSKA 2007, 2008) also draw attention to the fact that fallow lands are susceptible to invasion by alien species.

Methods of use of forest ecosystems have also changed over recent decades. In the early $20^{\text {th }}$ century traditional forms of use such as grazing and litter removal, were eliminated in forests, although in some regions they remained as an occasional practice until the 1980s. These changes resulted from the implementation of relevant regulations, and also from civilization progress and reduced demand for "historical forest services". The early $20^{\text {th }}$ century brought the dominance of forest management giving preference to the establishment of coniferous monoculture and limiting the use of selection-cutting system (OLACZEK 1976).

An essential stage of changing forest use was 'ecological forest management', introduced by legislation in early 1990s. New principles for forestgrowing included, e.g. better adjustment of tree species composition to habitats, wider use of complex felling, withdrawal of clearcutting in certain habitats, and limitation of use in so-called special forestry management units, including the gradual restructuring of coniferous tree monocultures established in past times. In the current understanding of the environmental role of forests the older methods, such as selection-cutting are gaining in importance again (PALUCH 2006).

The ecological effects of these changes can be observed in many forms today. One of their symptoms is the common regeneration of hornbeam forests, Carpinion, and beech forests, Fagion, (see: CZEREPKO 2004; KuROwsKI 2004; MACIEJEWSKI 2011) and the disappearance of some communities from the Polish forest landscape. The area covered by thermophilous oak forest Potentillo albaeQuercetum, subboreal mixed forest Serratulo-Pinetum, and pine forests with pasque-flowers Peucedano-Pinetum pulsatilletosum, is decreasing. All this leads to a decrease in the internal diversification of vegetation units (JAKUBOWSKA-GABARA 1993; MATUSZKIEWICZ 2007). It turns out that not only substitute communities 
described as degenerated forms (OLACZEK 1972), but also some well-known forest associations have developed and enlarged their area under long human pressure. There is only a difference in the time needed to initiate the transformation.

Agricultural or forest management has also ceased in areas with valuable natural features, those under legal protection, or in their direct neighbourhood (Kujawa-Pawlaczyk, Pawlaczyk 1997; Adamowski, Bomanowska 2008; Matysiak, DembeK 2008; MichalsKa-HeJduK, BomanowsKa 2009). Today there are ten forms of nature conservation in Poland established by law. National parks and reserves cover about $1.6 \%$ of Poland's area, while landscape parks and protected landscape areas account for over 30\% (GUS 2010). In these areas human pressure has been largely limited. Recently a significant impact on the increase in the surface of protected areas has been attributed to the European network of Natura 2000 sites, which in total covers about $20 \%$ of Poland and partly overlaps the national system for nature conservation. In protected areas where forest or agriculture management ceased, transformations in plant cover also contribute most frequently to a retreating of heliophilous species typical for grasslands, meadows and thermophilous forests (see: MichaliK 1990b; JAKUBOWSKA-GABARA 1991; KAźMIERCZAKOWA, GrodziŃSKa 2007; Michalska-HeJduk, BomanowsKa 2009). Active conservation measures, which are expensive and demand regular use, are implemented for the protection of these sites. Protected sites are also good testing grounds for studies on spontaneous ecological processes (see: FALIŃSKI 1986a; SZWAGRZYK 1994).

In summary, the agricultural and forest landscape of Poland has been considerably transformed over recent decades. Naturalization and increased human pressure coexist, and their effects are difficult to separate (BALON, GERMAN 2001). With respect to plant cover, their effects occur after different periods of time, but are widely present and have a clearly defined direction. For example, a decrease in areas of semi-natural grasslands and meadows, and dry coniferous and thermophilous forests is observed, as well as a decline in habitats with plants typical for these formations. Diversity of plant cover is decreasing, and mesophilous species, common and having high dispersion and growth potential, are spreading. Stenotopic 
species having poor competitive features and limited dispersion potential are declining. These transformations occur in parallel with the invasion of geographically alien species which take advantage of newly formed ecological niches. Both in agricultural and forest landscapes anthropophytes often play a significant role in the transformation of plant cover on abandoned sites where human pressure has ceased.

\section{EXAMPLES OF CURRENT GEOBOTANICAL STUDIES INDICATING CHANGES IN FLORA AND VEGETATION IN THE LANDSCAPE OF POLAND}

Changes in the intensity of land use have far-going consequences for the dynamics of flora and vegetation in Poland, and their registration and interpretation is a vital ecological subject. This gives botanists and ecologists an incentive to undertake detailed studies on the contemporary dynamic changes of plant cover in Polish landscape.

This volume of Folia Biologica et Oecologica contains papers on regional research (e.g. DZWONKo 2011; TOWPASZ, STACHURSKA-SWAKOŃ 2011; ZAŁUSKI 2011) and reports on studies carried out on specific objects, analyzing transformations in their flora and vegetation in various aspects and at various levels of organization.

Studies carried out in different geobotanical regions of Poland demonstrated that the directions and range of dynamic changes in plant cover are similar across the country. This is confirmed by studies in southern Poland (DzWONKO 2011; SKOWRONEK et al. 2011; ŚWIERCZ 2011; TOWPASZ, STACHURSKA-SWAKOŃ 2011; WILCZEK et al. 2011), south-eastern (CWENER, NOWAK 2011) and central (KIEDRZYŃSKI et al. 2011, KUROWSKI et al. 2011; WozIWODA, AMBROŻKIEWICZ 2011; Woziwoda, Komperda 2011; WoziwodA, MichalsKa-HeJduK 2011) as well as north and western regions of Poland (ADAMOWSKI, BOMANOWSKA 2011; RATYŃSKA et al. 2011; ZAŁUSKI 2011).

The formation of secondary forest phytocenoses, spontaneous or humanassisted, is a common ecological process observed today in the landscape. 
Therefore, the process of secondary succession is one of the most frequently studied problems in the presented papers. Detailed data on changes in species composition during secondary succession were obtained from permanent study plots (ADAMOWSKI, BomanowsKa 2011; DzWONKo 2011). Data from multi-annual observational series presented in the listed papers are highly valuable, as they explain in detail the reasons for and mechanisms of dynamics in contemporary plant cover on various scales, and also enable the development of models and the testing of ecological hypotheses. They are also unique because they require the process to be followed for decades longer than the lifespan of a single researcher, and therefore such studies are undertaken quite rarely.

Much more popular studies on secondary succession employ a chronosequence method based on the description of floristic compositions developed at a certain time or in a predicted time. Interesting conclusions on this type of study were made based on the analysis of changes in plant cover carried out using transects established on the patches abandoned in different periods (WozIWodA, AMBrożKIEWICZ 2011; WozIWOdA, MichalsKA-HeJduK 2011). Valuable information on general directions of succession were provided by floristical and phytosociological studies repeated after several decades on the sites of semi-natural protected communities (CWENER, NOWAK 2011; DZWONKo 2011). Study results confirmed the decline of precious meadow and grassland communities, associated with extensive management, even on the scale of entire regions (DZWONKO 2011; ZAŁUSKI 2011). This results in local and a regional decrease in floristical diversity and the formation of secondary forest and brushwood communities of lower floristical value.

An important group of papers is focused on changes in forest vegetation. Transformations of forest communities result, among other things, from regeneration after ceased use, and the introduction of legal protection (KIEDRZYŃSKI et al. 2011). Changes are also caused by the introduction and invasion of alien species (RATYŃSKA et al. 2011; SKOWRONEK et. al. 2011; TOWPASZ, STACHURSKASWAKOŃ 2011). Advancing fragmentation of the landscape, and isolation of old forest patches is a vital aspect in the formation of species composition in forest 
phytocenoses (DZWONKO 2011; WILCZEK et al. 2011). Interesting results were provide the application of new measures and analysis methods of floristic transformations in forest phytocoenoses (WILCZEK et al. 2011; SKOWRONEK et. al. 2011). Dynamic changes in forests, reflected by the increasing share of mesophilous species, can lead to changes in the range of communities across regions. Communities formed by heliophilous and thermophilous species decline, and the area of coniferous forest communities decreases (ZAŁUSKI 2011).

Dynamic changes in vegetation are also influenced by anthropogenic modification in soil conditions, like drainage (KUROWSKI et al. 2011; WoZIWODA, MiCHALSKA-HEJDUK 2011) or alkaline dust pollution (ŚwIERCZ 2011). Soil drainage leads to the decline of many hygrophilous forest communities and moors (ZAŁUSKI 2011). If habitats are at risk of damage, sites of valuable protected species require metaplantation to preserve the complete genetic pool of the native flora (KUROWSKI et al. 2011).

The above-listed examples confirm the nature of changes in the plant cover of Poland, and are a sample of current studies on the dynamics and structure of vegetation in Poland. As with papers on the dynamics of flora in protected areas (HoleKSA, SzWAGRZYK 2006), the study results contained in this volume of Folia Biologica et Oecologia contribute to the better understanding of the directions of changes. The detailed ecological and biological mechanisms driving these processes still remain a challenge for Polish geobotanists.

\section{REFERENCES}

ADAMOWSKI, W., BomanowsKa, A. 2007. Udział drzew i krzewów obcego pochodzenia $\mathrm{w}$ procesie zasiedlania gruntów porolnych $\mathrm{w}$ rejonie Puszczy Białowieskiej. Acta Botanica Warmiae et Masuriae 4: 309-320.

ADAmowski, W., Bomanowska, A. 2008. Zmiany użytkowania gruntów na obrzeżach cennych obiektów przyrodniczych a wkraczanie nierodzimych gatunków roślin. Przegl. Przyr. 19 (3/4): 3-17 .

AdAmowski, W., Bomanowska, A. 2011. Forest return on an abandoned field secondary succession under monitored conditions. Folia Biol. Oecol. 7: 49-73. 
Andrzejewski, R., Weigle, A. (eds). 2003. Róznorodność biologiczna Polski. Narodowa Fundacja Ochrony Środowiska, Warszawa.

BAKKER, J.P. 2005. Vegetation conservation, management and restoration. In: E. VAN DER MAAREL (ed.), Vegetation Ecology. Blackwell Publishing, pp. 309-331.

BALCERKIEWICZ, S. 1997. Wokół „krajobrazu porolnego” słów kilka. Przegl. Przyr. $8(1 / 2): 3-12$.

BAlON, J., German, K. 2001. Przemiany a funkcjonowanie środowiska przyrodniczego jako interdyscyplinarny problem badawczy. In: K. GERMAN, J. BALON (eds), Przemiany środowiska przyrodniczego Polski a jego funkcjonowanie. Problemy Ekologii Krajobrazu 10, Instytut Geografii i Gospodarki Przestrzennej UJ, PAEK, Kraków, pp. 23-27.

BAŃSKI, J. 1997. Przemiany rolniczego użytkowania ziemi w Polsce w latach 19751988. Pr. Geogr. IGiPZ PAN 168: 1-105.

BARABASZ, B. 1994. Wpływ modyfikacji tradycyjnych metod gospodarowania na przemiany roślinności łąk z klasy Molinio-Arrhenatheretea. Wiad. Bot. 38 (1-2): 85-94.

BARABASZ-KRASNY, B. 2002. Sukcesja roślinności na łąkach, pastwiskach i nieużytkach porolnych Pogórza Przemyskiego. Fragm Flor. Geobot. Polonica Suppl. 4: 3-81.

BĄBA, W. 2003. Changes in the structure and floristic composition of the limestone grasslands after cutting trees and shrubs and mowing. Acta Soc. Bot. Pol. 72 (1): $61-69$.

Bengtsson, J., Nilsson, S., Franc, A., Menozzi, P. 2000. Biodiversity, disturbances, ecosystem function and management of European forests. For. Ecol. Manage. 132: 39-50.

Bomanowska, A., AdAmowski, W. 2007. Grasses (Poaceae) in secondary succession of oak-hornbeam series in Białowieża Forest. In: L. FrEY (ed.), Biological issues in grasses. W. Szafer Institute of Botany, pp. 131-143.

Bomanowska, A., Adamowski, W. 2009. The role of woody species in the secondary succession under monitored conditions (Bialowieża Forest, NE Poland). In: D. IvanOva (ed.), Plant, fungal and habitat diversity investigation 
and conservation. Proceedings of IV Balkan Botanical Congress, Sofia, 20-26 June 2006. Institute of Botany, Bulgarian Academy of Sciences, Sofia, pp. 291295.

CroŁkosz, A., PoŁAwski, Z.F. 2006. Zmiany użytkowania ziemi w Polsce w drugiej połowie XX wieku. Przegląd Geograficzny 78 (2): 173-190.

CRUTZEN, P.J. 2002. Geology of mankind. Nature 415: 23.

CRUTZEN, P.J., STEFFEN, W. 2003. How long have we we been in the anthropocene era Climatic Change 61: 251-257.

Cwener, A., NowaK, M. 2011. Actual state and changes of flora and vegetation in the Broczówka steppe reserve. Folia Biol. Oecol. 7: 163-176.

CZEREPKO, J. 2004. Rola drzewostanu sosnowego w rozwoju fitocenozy na siedlisku lasu grądowego. Leśne Prace Badawcze 4: 77-102.

DZWONKO, Z. 2011. Effect of changes in land use during the 20th century on woodland and calcareous grassland vegetation in southern Poland. Folia Biol. Oecol. 7: 27-48.

DZWONKO, Z., LOSTER, S. 1992. Sppecies richness and seed dispersal to secondary. woods in southern Poland. J. Biogeogr. 19: 195-204.

DZWONKO Z., LOSTER, S. 1998. Dynamics of species richness and composition in a limestone grassland restored after tree cutting. J. Veg. Sci. 9: 387-394.

DZWONKO, Z., LOSTER, S. 2007. A functional analysis of vegetation dynamics in abandondoned and restored limestone grasslands. J. Veg. Sci. 18: 203-212.

EllenberG, H. 1988. Vegetation ecology of Central Europe. Cambridge University Press, Cambridge.

FALIŃSKI, J.B. 1986a. Vegetation dynamics in temperate lowland primeval forests. Ecological studies in Białowieża Forest. Geobotany 8. Dr W. Junk Publishers, Dordrecht/Boston/Lancaster, pp. 1-537.

FALIŃSKI, J.B. 1986b. Sukcesja roślinności na nieużytkach porolnych jako przejaw dynamiki ekosystemu wyzwolonego spod długotrwałej presji antropogenicznej. Wiad. Bot. 30 (1): 12-50.

FALIŃSKI, J.B. 1988a. Succession, regeneration and fluctuation in the Białowieża Forest (NE Poland). Vegetatio 77: 115-128. 
FALIŃSKI, J.B. 1998b. Invasive alien plants and vegetation dynamics. In: U. StARFinger, K. EdWARds, I. KowARIK, M. Williamson (eds), Plant invasions. Ecological consequences and human responses. Backhuys, Leiden, pp. 3-21.

FALKOWSKI, M. (ed.). 1983. Łąkarstwo i gospodarka łąkarska. PWRiL, Warszawa.

FIJAŁKOWSKI, D., ŚWIERCZYŃSKA, S. 1991. Zmiany powierzchni zespołów roślinności kserotermicznej na Wyżynie Lubelskiej. Prądnik, Pr. Muz. Szafera 3: $121-123$.

Foley, J.A., DeFries, R., Asner, G.P., BArford, C., Bonan, G., CArpenter, S.R., Chapin, F.S., Coe, M.T., Daily, G.C., Gibbs, H.K., Helkowski, J.H., Holloway, T., Howard, E.A., Kucharik, C.J., Monfreda, C., Patz, J.A., Prentice, I.C., RAmankutTy, N., SNyder, P.K. 2005. Global consequences of land use. Science 309: 570-574.

GRINN-GOFROŃ, A. 2007. Zbiorowiska zastępcze w monokulturach sosnowych na gruntach porolnych. Acta Botanica Warmiae et Masuriae 4: 269-282.

GUS 2010. Rocznik Statystyczny Rzeczpospolitej Polskiej. Zakład Wydawnictw Statystycznych, Warszawa.

HERBICHOWA, M. 1998. Ekologiczne studium rozwoju torfowisk wysokich właściwych na przykładzie wybranych obiektów ze środkowej części Pobrzeża Bałtyckiego. Wydawnictwo Uniwersytetu Gdańskiego, Gdańsk.

Hodgson, J.G., Grime, J.P., Wilson, P.J., Thompson, K., Band, S.R. 2005. The impacts of agricultural changes (1963-2003) on the grassland flora of Central England: processes and prospects. Basic Appl. Ecol. 6: 107-118.

HoleKsa, J., SzWAGRZYK, J. 2006. Zakres, tempo i mechanizmy zmian w przyrodzie terenów chronionych w Polsce - wprowadzenie. In: J. HOLEKSA (ed.), Zakres, tempo i mechanizmy zmian w przyrodzie terenów chronionych w Polsce. Studia Nat. 54, cz. I: 7-11.

JAKUBOwSKA-GABARA, J. 1991. Recesja zespołu świetlistej dąbrowy Potentillo albae-Quercetum Libb. 1933 w rezerwacie Trębaczew. Par. Nar. Rez. Przyr. 10 (3/4): 69-79. 
JAKUBOwSKA-GABARA, J. 1993. Recesja zespołu świetlistej dąbrowy Potentillo albae-Quercetum Libb. 1933 w Polsce. Wydawnictwo Uniwersytetu Łódzkiego, Łódź.

JASNOWSKI, M. 1972. Rozmiary i kierunki przekształceń szaty roślinnej torfowisk. Phytocoenosis 1 (3): 193-208.

JASNOWSKI, M., JASNOWSKA, J., MARKOWSKI, S. 1968. Ginące torfowiska wysokie i przejściowe w pasie nadbałtyckim Polski. Ochr. Przyr. 33: 69-124.

JERMACZEK, A. 2008. Zalesiać czy dać szanse naturze? Możliwości wykorzystania naturalnej sukcesji w zalesieniach. In: A. JERMACZEK (ed.), Zalesiać czy nie zalesiać? Wydawnictwo Klubu Przyrodników, Świebodzin, pp. 107-111.

JutrzenkA-Trzebiatowski, A. 1999. Wpływ człowieka na szatę leśną Polski północno-wschodniej w ciągu dziejów. Rozprawy i Materiały Ośrodka Badań Naukowych im. Wojciecha Kętrzyńskiego. Olsztyn.

KaŹMIERCZAKOWA, R., GrodziŃSKA, K. 2007. Przemiany zbiorowisk naskalnych i kserotermicznych w Pienińskim Parku Narodowym w ciągu ostatnich 35 lat XX w. In: J. HoleKSA (ed.), Zakres, tempo i mechanizmy zmian w przyrodzie terenów chronionych w Polsce. Studia Nat. 54, cz. I: 85-132.

KIEDRZYŃSKI, M., ZielińsKA, K., GRZELAK, P. 2011. Transformation of forest vegetation after 40 years of protection in the Tomczyce nature reserve (Central Poland). Folia Biol. Oecol. 7: 207-227.

KORNAŚ, J. 1977. Wpływ człowieka i jego gospodarki na szatę roślinną Polski flora synantropijna. In: W. SZAFER, K. ZARZYCKI (eds), Szata roślinna Polski. I. PWN, Warszawa, pp. 95-128.

KornAŚ, J., DubIEL, E. 1990. Przemiany zbiorowisk łąkowych w Ojcowskim Parku Narodowym w ostatnim trzydziestoleciu. Prądnik, Pr. Muz. Szafera 2: 97-106.

KuCHARSKI, L. 1999. Szata roślinna łąk Polski Środkowej i jej zmiany w XX stuleciu. Wydawnictwo Uniwersytetu Łódzkiego, Łódź.

Kujawa-PawlaczyK, J., PawlaczyK, P. 1997. Zmiany użytkowania ziemi w środkowej części Puszczy Drawskiej w ciągu ostatniego stulecia i ich geobotaniczne konsekwencje. Przegl. Przyr. 8 (1/2): 47-62. 
KUROWSKI, J.K. 2004. La degeneration et regeneration des phytocenoses forestières: l'exemple de la Pologne Centrale. Natura Mosana 57 (3): 57-76.

Kurowski, J.K., Koczywąs, E., PIEŃKOwski, M. 2011. Estimation of population size of Dentaria enneaphyllos in the vincinity of the Bełchatów brown coal mine and the attempt of its metaplantation. Folia Biol. Oecol. 7: 247-259.

ŁASKA, G. 1997. Kształtowanie się leśnych zbiorowisk zastępczych na terenach użytkowanych rolniczo. Przegl. Przyr. 8 (1/2): 77-86.

MACIEJEWSKI, Z. 2011. Spontaneous regeneration of the Carpathian beech forest in planted pine stands of the Roztocze National Park (The Roztocze Highlands, South-east Poland). Pol. J. Ecol. 59 (2): 235-248.

Matson, P.A., Parton, W.J., Power, A.G., Swift, M.J. 1997. Agricultural intensification and ecosystem properties. Science 277: 504-509.

MatuszKIEwicz, J.M. (ed.). 2007. Geobotaniczne rozpoznanie tendencji rozwojowych zbiorowisk leśnych w wybranych regionach Polski. Monografie IGiPZ PAN, 8: 1-980.

MATYSIAK, A., DĘBEK, W. 2008. Zalesienia na obszarach o wysokiej randze ochrony przyrody na przykładzie Kampinoskiego Parku Narodowego. In: A. JERMACZEK (ed.), Zalesiać czy nie zalesiać? Wydawnictwo Klubu Przyrodników, Świebodzin, pp. 87-105.

Meiners, S.J., PiCKetT, S.T.A., CAdenAsso M.L. 2002. Exotic plant invasions over 40 years of old field successions: community patterns and associations. Ecography 25: 215-223.

Michalik, S. 1990a. Przemiany roślinności kserotermicznej w czasie 20-letniej sukcesji wtórnej na powierzchni badawczej „Grodzisko” w Ojcowskim Parku Narodowym. Prądnik, Pr. Muz. Szafera 2: 43-52.

MichaLIK, S. 1990b. Sukcesja wtórna i problemy aktywnej ochrony biocenoz półnaturalnych w parkach narodowych i rezerwatach przyrody. Prądnik, Pr. Muz. Szafera 2: 175-198.

Michalska-Hejduk, D., Bomanowska, A. (eds). 2009. Rola Kampinoskiego Parku Narodowego w zachowaniu różnorodności biologicznej i krajobrazowej dawnych obszarów wiejskich. Kampinoski Park Narodowy, Łódź-Izabelin. 
NAAF, T, WOLF, M. 2011. Traits of winner and loser species indicate drivers of herb layer changes over two decades in forests of NW Germany. J. Veg. Sci. 22: 516527.

Niedrist, G., Tasser, E., LÜth, C., Dalla, Via J., Tappeiner, U. 2009. Plant diversity declines with recent land use changes in European Alps. Plant Ecol. 202: 195-210.

Nowicki, J., MARKs, M., WANIEC, M., BuCZYŃSKi, G. 1998. Ugorowanie gruntów jako element gospodarki ziemią w Polsce. Bibl. Fragm. Agron. 5.

OLACZEK, R. 1972. Formy antropogenicznej degeneracji leśnych zbiorowisk roślinnych w krajobrazie rolniczym Polski Niżowej. Wydawnictwo Uniwersytetu Łódzkiego, Łódź.

OlACZEK, R. 1976. Zmiany w szacie roślinnej Polski od połowy XIX wieku do lat bieżących. Zeszyty Problemowe Postępu Nauk Rolniczych 177: 369-402.

OlACZEK, R., KUCHARSKI, L., PISAREK, W. 1990. Zanikanie obszarów podmokłych i jego skutki środowiskowe na przykładzie województwa piotrkowskiego (zlewni Pilicy i Warty). Studia Ośrodka Dokumentacji Fizjograficznej 18: 141-199.

OrCzewsKa, A., Fernes, M. 2011. Migration of herb layer species into the poorest post-agricultural pine woods adjacent to ancient pine forests. Pol. J. Ecol. 59 (1): $75-85$.

PALUCH, J. 2006. Rębnia przerębowa jako nowoczesna metoda biologicznej racjonalizacji. Sylwan 10: 20-29.

Petit, S., Firbank, L. 2006. Predicting the risk of losing parcels of semi-natural habitat to intensive agriculture. Agric. Ecosyst. Environ. 115: 277-280.

Plan RozwoJu ObSZARów WiEJSKICH na lata 2004-2006. http://www.minrol.gov.pl/DesktopDefault.aspx?TabOrgId=1319\&LangId=0.

Poschlod, P., BAKKer, J. P., KAhMEN, S. 2005. Changing land use and its impact on biodiversity. Basic Appl. Ecol. 6: 93-98.

Program RozWoJu OBSZARów WIEJSKICH na lata 2007-2013. http://www.arimr.gov.pl/index.php?id=66\&id1=0\&id2=00.

RATYŃSKA, H., GRODZKi, M., WALDON, B., WACHOWIAK, E. 2011. Introduction of alien tree species and its influence on floristical composition and vegetation 
structure of acidophilous oak forests: the experimental plots in the Zielonka Forest. Folia Biol. Oecol. 7: 177-190.

Reidsma, P., Tekelenburg, T., Van den Berg, M., Alkemade, R. 2006. Impacts of land-use change on biodiversity: An assessment of agricultural biodiversity in the European Union. Agric. Ecosyst. Environ. 114: 86-102.

REJMÁNeK, M. 1999. Invasive plant species and invasible ecosystems. In: O.T. SANDLUnd, P.J. SCHEI, Á. VIKEN (eds), Invasive species and biodiversity management. Kluwer Academic Publishers, Dordrecht/Boston/London, pp. 79102.

Rewucki, M. 2008. Las rośnie sam, ale...? Zalesianie w Programie Rozwoju Obszarów Wiejskich. In: A. JERMACZEK (ed.), Zalesiać czy nie zalesiać? Wydawnictwo Klubu Przyrodników, Świebodzin, pp. 147-165.

Richardson, D.M., Williams, P.A., HobBS, R.J. 1994. Pine invasions in the-

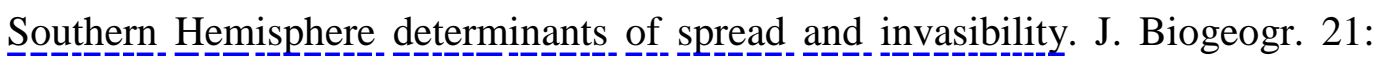
$511-527$.

SENDEK, A., BABCZYŃSKA-SENDEK, B. 1990. Problemy ochrony roślinności kserotermicznej w rezerwatach Góra Gipsowa i Ligota Dolna na Opolszczyźnie. Prądnik Pr. Muz. Szafera 2: 17-21.

Skolud, P. 2008. A co na to leśnicy? Lasy Państwowe a zalesianie gruntów porolnych. In: A. JERMACZEK (ed.), Zalesiać czy nie zalesiać? Wydawnictwo Klubu Przyrodników, Świebodzin, pp. 167-189.

SkowroneK, I., BABCZyŃSKA-SEndeK, B., ChMurA, D. 2011. An attempt at assessment of Alnetum incanae LÜDI 1921 transformations in the Skawica River valley (Beskid Żywiecki Mts). Folia Biol. Oecol. 7: 191-206.

SuKOPP, H. 1972. Wandel der Flora und Vegetation in Mitteleuropa unter dem Einfluß des Menschen. Ber. Landwirtsch. 50: 112-139.

SzAFER, W. 1977. Szata roślinna Polski Niżowej. In: W. SZAFER, K. ZARZYCKI (eds), Szata roślinna Polski. 2. PWN. Warszawa, pp. 17-188.

SzWAGRzYK, J. 1994. Co nauka jest winna ochronie przyrody? Przegl. Przyr. 5 (3/4): 3-15. 
SZWAGRZYK, J. 1997. Znaczenie gruntów porolnych dla ochrony przyrody: analiza doświadczeń i wnioski na przyszłość. Przegl. Przyr. 8 (1/2): 33-42.

ŚWIERCZ, A. 2011. Reaction of coniferous forest vegetation to particulate deposition under alkaline pressure. Folia Biol. Oecol. 7: 229-246.

TOWPASZ, K., StachursKa-SwaKoń, A. 2011. The analysis of the forest flora of the Strzyżowskie Foothills from the perspective of presence of anthropogenic species. Folia Biol. Oecol. 7: 99-110.

TYBiRK, K., StRAnDBERG B. 1999. Oak forest development as a result of historical land-use patterns and present nitrogen deposition. For. Ecol. Manage. 114: 97106.

URBAN, S. 2009. Zmiany w użytkowaniu ziemi rolniczej w Polsce. Journal of Agribusiness and Rural Development 2(12): 257-265.

VAN DER MAAREL, E. 1988. Vegetation dynamics: patterns in time and space. Vegetatio 77: 7-19.

Waldhardt, R., Simmering, D., Albrecht, H. 2003. Floristic diversity at the habitat scale in agricultural landscapes of Central Europe - summary, conclusions and perspectives. Agric. Ecosyst. Environ. 98: 79-85.

WALDON, B. 1999. Zanikanie rzadkich i chronionych gatunków muraw kserotermicznych krawędzi doliny Wisły (okolice Gruczna). Przegl. Przyr. 10 (34): $129-133$.

WILCZEK, Z., ROMAŃCZYK, M., BARĆ, A. 2011. Ancient woodlands' and synanthropic plants as indicators of maintenance of the forest communities in the nature reserves of the Oświęcim Basin. Folia Biol. Oecol. 7: 111-123.

WolsKI, J. 2007. Przekształcenia krajobrazu wiejskiego Bieszczadów Wysokich w ciągu ostatnich 150 lat. Pr. Geogr. IGiPZ PAN 214: 1-228.

WoziwodA, B., AmbrożKIEwicz, K. 2011. Diversity of forest and shrub communities as a result of site history and of extensive and intensive forest management (Glinno Ługi case study). Folia Biol. Oecol. 7: 149-162.

WoziwodA, B., Komperda, A. 2011. Anthropogenic causes of peatland species vanishing in Glinno Ługi area. Folia Biol. Oecol. 7: 139-148. 
Woziwoda, B., Michalska-Hejduk, D. 2011. Impact of land use changes and dynamic vegetation changes on vascular flora diversity in Małków-Martochów (Warta River valley). Folia Biol. Oecol. 7: 125-138

WóJCIK, R. 1996. Sukcesja wtórna na gruntach porolnych. Sylwan 140 (8): 63-68.

Zalasiewicz, J., Williams, M., Smith, A., Barry, T.L., Coe, A.L., Bown, P.R., Brenchley, P., Cantrill, D., Gale, A., Gibbard, P., Gregory, F.J., Hounslow, M.W., Kerrk, A.C., Pearson, P., Knox, R., Powell, J., Waters, C., Marshall, J., OAtes, M., Rawson, P., Stone, P. 2008. Are we now living in the Anthropocene? GSA Today 18 (2): 4-8.

ZAŁUSKI, T. 2011. Vegetation transformations of Kujawy-Pomerania region in the last twenty years period. Folia Biol. Oecol. 7: 75-98.

ZERBE, S. 2002. Restoration of natural broad-leaved woodland in Central Europe on sites with coniferous forest plantations. For. Ecol. Manage. 167: 27-42. 